\title{
Aerosol effects on the photochemistry in Mexico City during MCMA-2006/MILAGRO campaign
}

\author{
G. $\mathbf{L i}^{1,2}$, N. Bei ${ }^{1}$, X. Tie ${ }^{3}$, and L. T. Molina ${ }^{1,2}$ \\ ${ }^{1}$ Molina Center for Energy and the Environment, La Jolla, CA, USA \\ ${ }^{2}$ Massachusetts Institute of Technology, Cambridge, MA, USA \\ ${ }^{3}$ National Center for Atmospheric Research, Boulder, CO, USA \\ Received: 9 February 2011 - Published in Atmos. Chem. Phys. Discuss.: 14 March 2011 \\ Revised: 30 May 2011 - Accepted: 30 May 2011 - Published: 1 June 2011
}

\begin{abstract}
In the present study, the impact of aerosols on the photochemistry in Mexico City is evaluated using the WRFCHEM model for the period from 24 to 29 March during the MCMA-2006/MILAGRO campaign. An aerosol radiative module has been developed with detailed consideration of aerosol size, composition, and mixing. The module has been coupled into the WRF-CHEM model to calculate the aerosol optical properties, including optical depth, single scattering albedo, and asymmetry factor. Calculated aerosol optical properties are in good agreement with the surface observations and aircraft and satellite measurements during daytime. In general, the photolysis rates are reduced due to the absorption by carbonaceous aerosols, particularly in the early morning and late afternoon hours with a long aerosol optical path. However, with the growth of aerosol particles and the decrease of the solar zenith angle around noontime, aerosols can slightly enhance photolysis rates when ultraviolet (UV) radiation scattering dominates UV absorption by aerosols at the lower-most model layer. The changes in photolysis rates due to aerosols lead to about $2-17 \%$ surface ozone reduction during daytime in the urban area in Mexico City with generally larger reductions during early morning hours near the city center, resulting in a decrease of $\mathrm{OH}$ level by about $9 \%$, as well as a decrease in the daytime concentrations of nitrate and secondary organic aerosols by $5-6 \%$ on average. In addition, the rapid aging of black carbon aerosols and the enhanced absorption of UV radiation by organic aerosols contribute substantially to the reduction of photolysis rates.
\end{abstract}

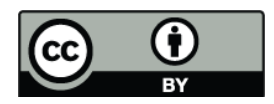

Correspondence to: $\mathrm{G} . \mathrm{Li}$ (lgh@mce2.org)

\section{Introduction}

Atmospheric particulate matter or aerosols, formed from natural and anthropogenic sources, are a chemical mixture of solid and liquid particles suspended in the atmosphere, with diameters ranging from a few nanometers to several micrometers or more. Aerosols influence climate directly by scattering or absorbing a fraction of the incoming solar radiation to cool or warm the atmosphere, and indirectly via their roles as cloud condensation nuclei (CCN) and ice nuclei (IN), by modifying optical properties and lifetime of clouds (e.g., Penner et al., 2001; Zhang et al., 2007). Additionally, scattering or absorbing a fraction of solar radiation by aerosols also increase or decrease photolysis rates in the atmosphere, affecting ozone $\left(\mathrm{O}_{3}\right)$ formation and atmospheric oxidation capacity (Tie et al., 2003, 2005; Li et al., 2005).

Numerous studies have evaluated the aerosol effects on photolysis rates and $\mathrm{O}_{3}$ formation in the atmosphere. Dickerson et al. (1997) considered the effect of absorbing aerosols in the planetary boundary layer (PBL) in model simulations and found that UV-absorbing aerosols reduce the calculated $\mathrm{O}_{3}$ mixing ratios by up to $24 \mathrm{ppbv}$. Jacobson (1998) showed that aerosol particles containing a black (elemental) carbon core coated by organic material and/or other material might reduce $\mathrm{O}_{3}$ by $5-8 \%$ in Los Angeles. Castro et al. (2001) found an even larger reduction in the photolysis coefficients in Mexico City due to absorbing aerosols compared to the Los Angeles study. The photolysis rate of $\mathrm{NO}_{2}$ was decreased by $10-30 \%$ and surface $\mathrm{O}_{3}$ was reduced by 30 $40 \mathrm{ppb}$ in their simulations using a simple zero-dimensional photochemical model. Jonson et al. (2000) found small effects on monthly averaged ozone with the inclusion of aerosols in the simulations of a regional-scale photochemistry model. Zanis et al. (2002) concluded that increasing absorbing aerosol (Sahara dust) content could reduce net ozone production rate in box model calculations constrained by the

Published by Copernicus Publications on behalf of the European Geosciences Union. 
measurements. Balis et al. (2002) reported the reduction of the photolysis rates during a Sahara dust event by radiative transfer model calculations and aircraft measurements. Another study by Stockwell and Goliff (2004) suggested that the impact of photolysis on relative $\mathrm{O}_{3}$ concentrations varied depending on the ratio of volatile organic compounds (VOCs) to $\mathrm{NO}_{\mathrm{x}}\left(\mathrm{NO}+\mathrm{NO}_{2}\right)$. Additionally, Martin et al. (2003) used global three-dimensional chemical transport models (CTM) to study the photochemical effects of aerosols on tropospheric chemistry and they found important aerosol effects from reduction in photolysis frequencies. Aerosols decrease the $\mathrm{O}_{3} \rightarrow \mathrm{O}\left({ }^{1} \mathrm{D}\right)$ photolysis frequency at the surface by 5$15 \%$ throughout most of the Northern Hemisphere. Using a global tropospheric CTM, Bian et al. (2003) found that, globally averaged, the impacts of aerosols on photolysis alone is to increase tropospheric $\mathrm{O}_{3}$ by 0.63 Dobson units and increase tropospheric $\mathrm{CH}_{4}$ by $130 \mathrm{ppb}$. Bian and Zender (2003) also evaluated the impact of mineral dust on photolysis rates in the troposphere using a CTM. They showed that the photolysis perturbation due to dust dominates limited regions in the low to middle troposphere and $\mathrm{O}_{3}$ change due to photolysis depends not only on the dust vertical structure but also on the availability of $\mathrm{O}_{3}$ precursors.

During the MCMA-2006 (Mexico City Metropolitan Area) field campaign as part of the MILAGRO (Megacity Initiative: Local and Global Research Observations) project in March 2006, an extensive data set was obtained, including high time resolution of ambient aerosol optical properties (Molina et al., 2010), which provides an opportunity to investigate the impact of aerosols on the photochemistry in a polluted urban area. Marley et al. (2009) measured the aerosol absorption and scattering in the MCMA during MILAGRO; they reported that the single scattering albedo (SSA) at $550 \mathrm{~nm}$ for the fine mode aerosols ranged from 0.47 to 0.92 at the T0 supersite (located in the northern part of Mexico City), suggesting that Mexico City environment has high levels of fine mode absorbing aerosols. Using direct measurements of the optical and microphysical characteristics of atmospheric soot particles, Moffet and Prather (2009) found that, within $3 \mathrm{~h}$ after sunrise, photochemical activity leads to the rapid conversion of fresh non-spherical soot to aged spherical coated soot particles, which become the dominant contributor to aerosol absorption during mid-day. Barnard et al. (2008) used the data measured during MCMA2003 (Molina et al., 2007) and MILAGRO-2006 to investigate the absorption of solar radiation by the organic component of aerosols. They reported that the organic aerosol enhances the absorption in the near-UV spectral range (250 to $400 \mathrm{~nm}$ ) and the mass absorption cross section for the organic aerosol decreases from $10.5 \mathrm{~m}^{2} \mathrm{~g}^{-1}$ at $300 \mathrm{~nm}$ to around zero at about $500 \mathrm{~nm}$.

The objective of the present study is to examine the aerosol impact on the photochemistry in Mexico City using the WRF-CHEM model based on the measurements taken during MCMA-2006. We have developed a new module to ac- count for the aerosol radiative properties, including the optical depth, SSA, and asymmetry factor. The impacts from black carbon $(\mathrm{BC})$ rapid aging and enhanced absorption of UV radiation by organic aerosols $(\mathrm{OA})$ are included in the model. The model configuration is described in Sect. 2; results of the modeling studies and comparisons are presented in Sect. 3; the discussion and summary are given in Sect. 4.

\section{Model and method}

\subsection{WRF-CHEM model}

The WRF-CHEM model used in the present study is developed by Li et al. $(2010,2011)$ at the Molina Center, with a new flexible gas phase chemical module which can be utilized under different chemical mechanisms, including CBIV, RADM2, and SAPRC. The gas-phase chemistry is solved by an Eulerian backward Gauss-Seidel iterative technique with a number of iterations. The short-lived species, such as $\mathrm{OH}$ and $\mathrm{O}\left({ }^{1} \mathrm{D}\right)$, are assumed to be in the steady state. The solution is iterated until all species are within $0.1 \%$ of their previous iterative values. For the aerosol simulations, the CMAQ (version 4.6) aerosol module developed by EPA, which was designed to be an efficient and economical depiction of aerosol dynamics in the atmosphere, is used in the WRF-CHEM model (Binkowski and Roselle, 2003). In this aerosol component, the particle size distribution is represented as the superposition of three lognormal sub-distributions, called modes. The processes of coagulation, particle growth by the addition of mass, and new particle formation are included. The wet deposition also follows the method used in the CMAQ. Surface deposition of chemical species is parameterized following Wesely (1989). The photolysis rates are calculated using the FTUV (Tie et al., 2003; Li et al., 2005).

The inorganic aerosols are predicted in the WRFCHEM model using ISORROPIA version 1.7 (http://nenes. eas.gatech.edu/ISORROPIA/), which calculates the composition and phase state of an ammonium-sulfate-nitratechloride-sodium-calcium-potassium-magnesium-water inorganic aerosol in thermodynamic equilibrium with gas phase precursors. This kind of thermodynamic equilibrium is delicately dependent on the humidity and temperature. In this study, ISORROPIA is mainly applied to predict the thermodynamic equilibrium between the ammonium-sulfatenitrate-water aerosols and their gas phase precursors $\mathrm{H}_{2} \mathrm{SO}_{4}$ $\mathrm{HNO}_{3}-\mathrm{NH}_{3}$-water vapor.

The secondary organic aerosol (SOA) formation is simulated using a non-traditional SOA model including the volatility basis-set modeling method in which primary organic components are assumed to be semi-volatile and photochemically reactive and are distributed in logarithmically spaced volatility bins as described previously ( $\mathrm{Li}$ et al., 2011). The partitioning of semi-volatile organic species 
is calculated using the algorithm suggested by Koo et al. (2003), in which the bulk gas and particle phases are in equilibrium and all condensable organics form a pseudoideal solution (Odum et al., 1996). Nine surrogate species with saturation concentrations from $10^{-2}$ to $10^{6} \mu \mathrm{g} \mathrm{m}^{-3}$ at room temperature are used for the primary organic aerosol (POA) components following the approach of Shrivastava et al. (2008). The SOA contribution from glyoxal and methylglyoxal is also included (Li et al., 2011).

In order to consider the effects of aerosols on the photochemistry and meteorology, an aerosol radiative module has been developed and incorporated into the WRF-CHEM model described in the following sections.

\subsection{Aerosol and cloud radiative module}

In the aerosol module, aerosols are represented by a threemoment approach with a lognormal size distribution:

$$
n(\ln D)=\frac{N}{\sqrt{2 \pi} \ln \sigma_{\mathrm{g}}} \exp \left[-\frac{1}{2}\left(\frac{\ln D-\ln D_{\mathrm{g}}}{\ln \sigma_{\mathrm{g}}}\right)^{2}\right]
$$

where $D$ is the particle diameter, $N$ is the number distribution of all particles in the distribution, $D_{\mathrm{g}}$ is the geometric mean diameter, and $\sigma_{\mathrm{g}}$ is the geometric standard deviation.

To calculate the aerosol optical properties, the aerosol spectrum is first divided into 48 bins from $0.002 \mu \mathrm{m}$ to $2.5 \mu \mathrm{m}$, with radius $r_{i}$. When the bin's radius is less than $0.1 \mu \mathrm{m}$, the interval of bins ranges from 0.001 to $0.005 \mu \mathrm{m}$. When the bin's radius is greater than $0.1 \mu \mathrm{m}$, the interval is increased to 0.025 to $0.25 \mu \mathrm{m}$. The aerosols are classified into four types: (1) internally mixed sulfate, nitrate, ammonium, hydrophilic organics, hydrophilic black carbon, and water; (2) hydrophobic organics; (3) hydrophobic black carbon; and (4) other unidentified aerosols (such as dust in this study). These four kinds of aerosols are assumed to be mixed externally. For the internally mixed aerosols, the complex refractive index at a given wavelength $(\lambda)$ is calculated based on the volume-weighted average of the individual refractive index. Given the particle size and complex refractive index, the extinction efficiency $\left(Q_{\mathrm{e}}\right)$, the SSA $\left(\omega_{\mathrm{a}}\right)$, and the asymmetry factor $\left(g_{\mathrm{a}}\right)$ are calculated using the Mie theory at a given wavelength. To avoid repeating Mie scattering calculation, the look-up tables of $Q_{\mathrm{e}}, \omega_{\mathrm{a}}$, and $g_{\mathrm{a}}$ are constructed using particle sizes and refractive indices. The aerosol optical parameters are interpolated linearly from the look-up tables with the calculated refractive index and particle size in the module.

The aerosol optical thickness (AOT or $\tau_{\mathrm{a}}$ ) at a given wavelength $\lambda$ in a given atmospheric layer $k$ is determined by the summation over all types of aerosols and all bins:

$$
\tau_{\mathrm{a}}(\lambda, k)=\sum_{i=1}^{48} \sum_{j=1}^{4} Q_{\mathrm{e}}\left(\lambda, r_{i}, j, k\right) \pi r_{i}^{2} n\left(r_{i}, j, k\right) \Delta z_{k}
$$

where $n\left(r_{i}, j, k\right)$ is the number concentration of $j$-th kind of aerosols in $i$-th bin. $\Delta z_{k}$ is the depth of an atmospheric layer. The weighted-mean values of $\sigma$ and $g$ are then calculated by (d'Almeida et al., 1991):

$$
\begin{aligned}
& \omega_{\mathrm{a}}(\lambda, k)= \\
& \sum_{i=1}^{48} \sum_{j=1}^{4} Q_{\mathrm{e}}\left(\lambda, r_{i}, j, k\right) \pi r_{i}^{2} n\left(r_{i}, j, k\right) \omega_{a}\left(\lambda, r_{i}, j, k\right) \Delta z_{k} / \tau_{\mathrm{a}}(\lambda, k) \\
& g_{\mathrm{a}}(\lambda, k)= \\
& \sum_{i=1}^{48} \sum_{j=1}^{4} Q_{\mathrm{e}}\left(\lambda, r_{i}, j, k\right) \pi r_{i}^{2} n\left(r_{i}, j, k\right) \omega_{\mathrm{a}}\left(\lambda, r_{i}, j, k\right) g_{\mathrm{a}}\left(\lambda, r_{i}, j, k\right) \Delta z_{k} \\
& \sum_{i=1}^{48} \sum_{j=1}^{4} Q_{\mathrm{e}}\left(\lambda, r_{i}, j, k\right) \pi r_{i}^{2} n\left(r_{i}, j, k\right) \omega_{\mathrm{a}}\left(\lambda, r_{i}, j, k\right) \Delta z_{k}
\end{aligned}
$$

When the wavelength-dependent aerosol radiative properties $\tau_{\mathrm{a}}, \omega_{\mathrm{a}}$, and $g_{\mathrm{a}}$ are obtained, they can be used in the short wave radiative transfer modules in the WRF-CHEM model. The aerosol refractive indices used for Mie scattering calculation are listed in Table 1. In the base case simulations, the $\mathrm{BC}$ aging from the hydrophobic to the hydrophilic state occurs at a pseudo first order rate of $9.26 \times 10^{-5} \mathrm{~s}^{-1}$ (Moffet and Prather, 2009) during daytime and $7.10 \times 10^{-6} \mathrm{~s}^{-1}$ (Cooke and Wilson, 1996) during nighttime. As suggested by Moffet and Prather (2009), the effective density is $0.7 \mathrm{~g}$ $\mathrm{cm}^{-3}$ for fresh BC and $1.8 \mathrm{~g} \mathrm{~cm}^{-3}$ for aged BC. In order to implement the enhanced absorption by OA in Mexico City observed by Barnard et al. (2008), the imaginary refractive index of POA measured by Kirchstetter et al. (2004) is employed in the present study (Table 1).

Clouds in the troposphere influence photolysis rates by scattering incoming solar radiation. In order to consider the effect of clouds on solar radiation and photolysis rates, we calculate the cloud optical depth $\left(\tau_{\mathrm{c}}\right)$ in an atmospheric layer with the thickness $\Delta \mathrm{z}_{k}(\mathrm{~m})$ using the approach suggested by Klein and Jacob (1999):

$\tau_{\mathrm{c}}=0.15893 W_{\mathrm{c}} \Delta z_{k}$

where $W_{\mathrm{c}}$ is the total liquid plus ice water content $\left(\mathrm{g} \mathrm{m}^{-3}\right)$. The cloud single scattering albedo $\left(\omega_{\mathrm{c}}\right)$ is assumed to be 0.99 and the asymmetry factor $\left(g_{\mathrm{c}}\right)$ is assumed to be 0.85 (Matthijsen et al., 1998). For the photochemical impact of aerosols and clouds, the FTUV developed by Tie et al. (2005) is used to calculate the photolysis frequencies.

\subsection{Model configuration}

Two three-day episodes are selected in the present study: (1) 24-26 March, 2006, and (2) 27-29 March 2006, representing typical " $\mathrm{O}_{3}$-Convection South" and " $\mathrm{O}_{3}$-Convection North" meteorological conditions in Mexico City, respectively (de Foy et al., 2008), with minor impacts of biomass burning. $\mathrm{O}_{3}$-Convection South takes place when there is a 
Table 1. Aerosol optical constants used in the calculation of aerosol optical properties.

\begin{tabular}{lrr}
\hline Aerosols & $\begin{array}{r}\text { Refractive Index } \\
(\lambda=400 \mathrm{~nm})\end{array}$ & $\begin{array}{r}\text { Refractive Index } \\
(\lambda=550 \mathrm{~nm})\end{array}$ \\
\hline Black carbon & $1.75-0.73 i$ & $1.75-0.72 i$ \\
Primary organic aerosol & $1.42-0.11 i$ & $1.42-0.03 i$ \\
Secondary organic aerosol & $1.42-2.0 \times 10^{-3} i$ & $1.42-2.0 \times 10^{-3} i$ \\
Sulfate & $1.44-1.0 \times 10^{-8} i$ & $1.43-1.0 \times 10^{-8} i$ \\
Nitrate & $1.44-1.0 \times 10^{-8} i$ & $1.43-1.0 \times 10^{-8} i$ \\
Ammonium & $1.44-1.0 \times 10^{-8} i$ & $1.43-1.0 \times 10^{-8} i$ \\
Water & $1.34-2.1 \times 10^{-10} i$ & $1.34-2.5 \times 10^{-9} i$ \\
Dust & $1.53-8.5 \times 10^{-3} i$ & $1.53-5.5 \times 10^{-3} i$ \\
\hline
\end{tabular}

weak northerly wind component aloft with rain in the southern part of the Mexico City basin. $\mathrm{O}_{3}$-Convection North takes place when there is a weak southerly wind component aloft with a gap flow and rain in the northern part of the basin. The WRF-CHEM model is configured with one grid with spacing of $3 \mathrm{~km}(99 \times 99$ grid points) centered at $19.538^{\circ} \mathrm{N}$ and $99^{\circ} \mathrm{E}$ (Fig. 1). Thirty-five vertical levels are used in a stretched vertical grid with spacing ranging from $50 \mathrm{~m}$ near the surface, to $500 \mathrm{~m}$ at $2.5 \mathrm{~km}$ and $1 \mathrm{~km}$ above $14 \mathrm{~km}$. The model employs the Lin microphysics scheme (Lin et al., 1983), the Yonsei University (YSU) PBL scheme (Noh et al., 2001), the Noah land-surface model (Chen and Dudhia, 2001), the longwave radiation parameterization (Mlawer et al., 1997), and the shortwave radiation parameterization (Dudhia, 1989). The meteorological initial and boundary conditions are from NCEP $1^{\circ} \times 1^{\circ}$ reanalysis data. The chemical initial and boundary conditions are interpolated from MOZART 3-hour output (Horowitz et al., 2003). The emission inventory (EI) used in the present study is the 2006 EI developed at Molina Center with the primary PM emissions (Song et al., 2010). The POA emissions are redistributed following the study of Tsimpidi et al. (2010).

We first perform the WRF-CHEM simulations with the impact of aerosols on photolysis frequencies as the base case to evaluate the model performance. Several sensitivity studies are conducted to evaluate the aerosol effects on the photochemistry and the contribution of the $\mathrm{BC}$ rapid aging and the enhanced absorption of UV radiation by POA to the aerosol absorption in Mexico City. The case without the aerosol impact on photolysis frequencies is used as the reference to compare with other cases to assess the changes caused by each individual scenario.

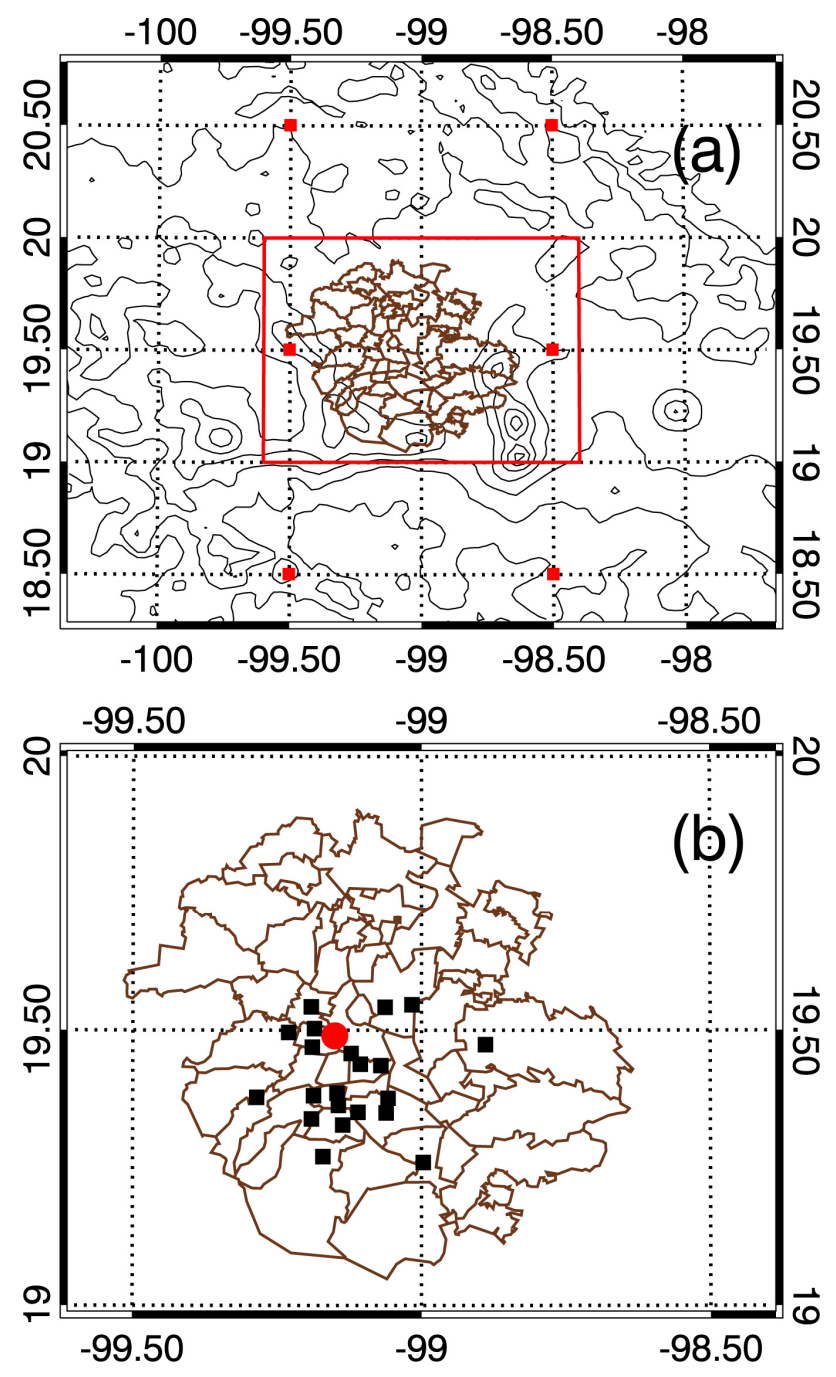

Fig. 1. WRF-CHEM simulation domain. Black filled squares represent the RAMA (Mexico City Ambient Air Monitoring Network) sites. The red filled circle represents the T0 supersite and the red filled squares denote the area with MODIS measurements.

\section{Results}

\subsection{Aerosol simulations}

The impact of aerosols on the photolysis rates depends on the aerosol loading in the atmosphere. Thus, in order to evaluate the impact of aerosols on the photolysis rates in the chemical transport model, the simulations of aerosol concentrations need to be carefully evaluated. Figure 2 shows the temporal variations of simulated and observed aerosols at $\mathrm{T} 0$ site. The WRF-CHEM model performs reasonably well in simulating the aerosol variations compared with measurements at T0 except for sulfate aerosols. In terms of statistical comparisons of simulated and measured aerosol concentrations, the IOA (index of agreement) of BC, POA, SOA and nitrate 

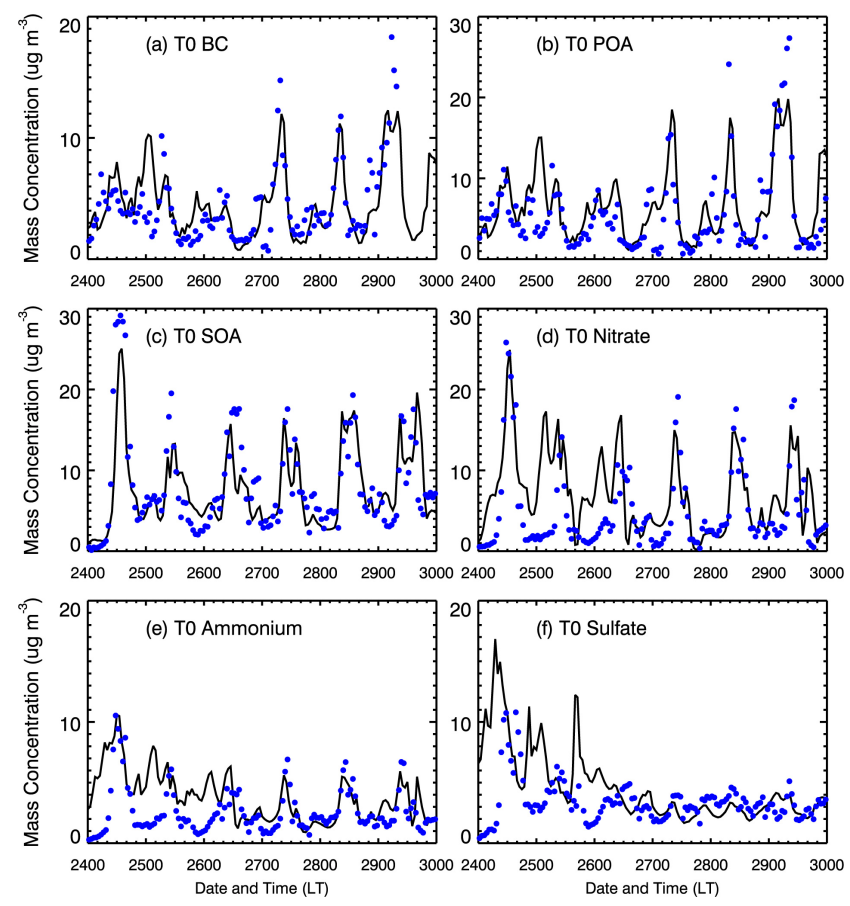

Fig. 2. Diurnal variations of measured (blue dots) and simulated (black line) aerosol concentrations at T0 during the period from 24 to 29 March, 2006. The x-axis labels (named date and time) represent day and hour (DDHH). For example, 2400 represents 00 local time on 24 March.

exceeds 0.80 , indicating good agreement of simulations of these aerosol components with measurements (Table 2). For the primary components, $\mathrm{BC}$ and POA that are directly emitted into the atmosphere in particulate form, the WRF-CHEM model reproduces the measured variation of $\mathrm{BC}$ and $\mathrm{POA}$ during the second episode (27-29 March), but it frequently overestimates during the first episode (24-26 March), particularly at night when the pollutants are transported from the Tula industrial complex located $70 \mathrm{~km}$ northwest of the city (de Foy et al., 2009). The secondary aerosols, such as nitrate and SOA, are mainly formed from the atmospheric processing of gaseous precursors. As shown in Fig. 2, the observed nitrate and SOA exhibit clearly two peaks around 10:00 and 14:00 LT (local time) from 25 to 29 March. The model reproduces well the two peaks, although the timing of the second peak is somewhat delayed due to the slow movement of the simulated plumes in the afternoon (Li et al 2010, 2011). However, the model has some difficulties in simulating the sulfate aerosols with the IOA of 0.42 (Table 2), which are influenced by multiple sources in Mexico City. In addition to the inefficient formation through the gas phase reaction of $\mathrm{SO}_{2}$ with $\mathrm{OH}$, other sources, such as the oxidation of $\mathrm{SO}_{2}$ in cloud droplets as well as the transport of direct emissions of sulfate from the Tula industrial complex and the Popocatepetl volcano (located $70 \mathrm{~km}$ in the southeast of the city) may play a key role in the formation of sulfate particles in Mexico City (de Foy et al., 2009). The uncertainties of sulfate emissions from the Tula industrial complex and the volcano have significant impacts on the sulfate aerosol simulations in Mexico City.

Vertical distributions of aerosols also play an important role in the evaluation of aerosol impacts on solar radiation. Measurements from research aircrafts deployed during MILAGRO provide detailed spatial and temporal variation of aerosols that are not available from the surface sites. In this study, the measured nitrate, ammonium and sulfate aerosols using the PILS-IC techniques on the G-1 research aircraft are compared with the WRF-CHEM model simulations on 26 and 27 March (see Fig. 3). The model is able to capture the plumes observed by the aircraft on 26 and 27 March. The model reproduces the variation of nitrate and ammonium aerosols, but shows some differences of the aerosol concentrations in some plumes. For sulfate aerosols, the calculation of the model is consistent with the measurement on March 27, but overestimates several spikes occurred on 26 March when the plumes are influenced by the Tula industrial complex. The IOA for aloft nitrate, ammonium and sulfate aerosols are $0.82,0.82$, and 0.58 on 26 March, and $0.85,0.84$ and 0.88 on 27 March, respectively. Furthermore, we have compared the model results with the BC measured by the SP2 (Single Particle Soot Photometer) and the nitrate, ammonium, sulfate, and total organics components measured by the Aerodyne Time-of-Flight Mass Spectrometer (ToFAMS) onboard C-130 on 29 March (see Fig. 4) (Molina et al., 2010). The results demonstrate that the simulated variability of BC captures several measured spikes, which are resulted from the transport of city plumes. Since BC can be considered as a passive tracer during the dry season, the $\mathrm{BC}$ simulation suggests that the model is able to simulate the transport of city plumes during this field campaign. Although the calculated variability is similar to the observations for nitrate, ammonium, and total organic aerosols, the calculated concentrations are generally underestimated compared to the measurements. In addition, on 29 March, the plumes formed in Mexico City move northwest in the afternoon, derived by the well organized south and northeast winds from outside of the basin ( $\mathrm{Li}$ et al., 2011). The sulfate aerosols emitted directly by the volcano occasionally influence the plumes over the city (de Foy et al., 2009). The observed spikes of sulfate aerosols from the volcano are generally well reproduced by the model.

\subsection{Aerosol optical properties}

The calculated aerosol optical properties, including AOT and SSA, are evaluated using the available measurements from the surface site, aircraft and satellite. The simulated AOT at $440 \mathrm{~nm}$ is first verified using the sun photometer measurements from a ground based station of Aerosol Robotic Network (AERONET) located at T0 (de Almeida Castanho et 
Table 2. Statistical comparisons of simulated and measured aerosol concentrations at T0 and along the flight tracks of research aircrafts (G1 and C-130).

\begin{tabular}{|c|c|c|c|c|c|c|c|c|c|c|c|c|}
\hline \multirow[b]{2}{*}{ Aerosols } & \multicolumn{3}{|c|}{$\begin{array}{c}\text { T0 Supersite } \\
\text { (24 to } 29 \text { March) }\end{array}$} & \multicolumn{3}{|c|}{ G1 on 26 March } & \multicolumn{3}{|c|}{ G1 on 27 March } & \multicolumn{3}{|c|}{ C-130 on 29 March } \\
\hline & $\begin{array}{r}\mathrm{NMB} \\
(\%)\end{array}$ & $\begin{array}{r}\text { RMSE } \\
\left(\mu \mathrm{g} \mathrm{m}^{-3}\right)\end{array}$ & IOA & $\begin{array}{r}\mathrm{NMB} \\
(\%)\end{array}$ & $\begin{array}{r}\text { RMSE } \\
\left(\mu \mathrm{g} \mathrm{m}^{-3}\right)\end{array}$ & IOA & $\begin{array}{r}\text { NMB } \\
(\%)\end{array}$ & $\begin{array}{r}\text { RMSE } \\
\left(\mu \mathrm{g} \mathrm{m}^{-3}\right)\end{array}$ & IOA & $\begin{array}{r}\mathrm{NMB} \\
(\%)\end{array}$ & $\begin{array}{r}\text { RMSE } \\
\left(\mu \mathrm{g} \mathrm{m}^{-3}\right)\end{array}$ & IOA \\
\hline $\mathrm{BC}$ & 3.5 & 2.2 & 0.85 & & & & & & & 51 & 0.21 & 0.75 \\
\hline POA & 19 & 3.5 & 0.86 & & & & & & & & & \\
\hline SOA & -5.0 & 3.6 & 0.88 & & & & & & & & & \\
\hline Nitrate & 41 & 4.5 & 0.80 & -49 & 1.5 & 0.82 & -0.34 & 2.7 & 0.85 & -61 & 3.8 & 0.78 \\
\hline Ammonium & 46 & 2.3 & 0.67 & -42 & 0.65 & 0.82 & -28 & 1.0 & 0.84 & -57 & 1.6 & 0.64 \\
\hline Sulfate & 36 & 3.4 & 0.42 & 23 & 0.96 & 0.58 & -3.1 & 0.21 & 0.88 & -10 & 2.3 & 0.46 \\
\hline
\end{tabular}

The normalized mean bias (NMB), the root mean square error (RMSE), and the index of agreement (IOA) are defined as: NMB $=\frac{\sum_{i=1}^{N}\left(P_{i}-O_{i}\right)}{\sum_{i=1}^{N} O_{i}}, \operatorname{RMSE}=\left[\frac{1}{N} \sum_{i=1}^{N}\left(P_{i}-O_{i}\right)^{2}\right]^{\frac{1}{2}}$, and IOA $=1-\frac{\sum_{i=1}^{N}\left(P_{i}-O_{i}\right)^{2}}{\sum_{i=1}^{N}\left(\left|P_{i}-\bar{O}\right|+\left|O_{i}-\bar{O}\right|\right)^{2}}$. Where $P_{i}$ and $O_{i}$ are the predicted and observed pollutant concentration, respectively. $N$ is the total number of the predictions used for comparisons, and $\bar{O}$ denotes the average of the observation. The IOA ranges from 0 to 1 , with 1 indicating perfect agreement between model and observation.
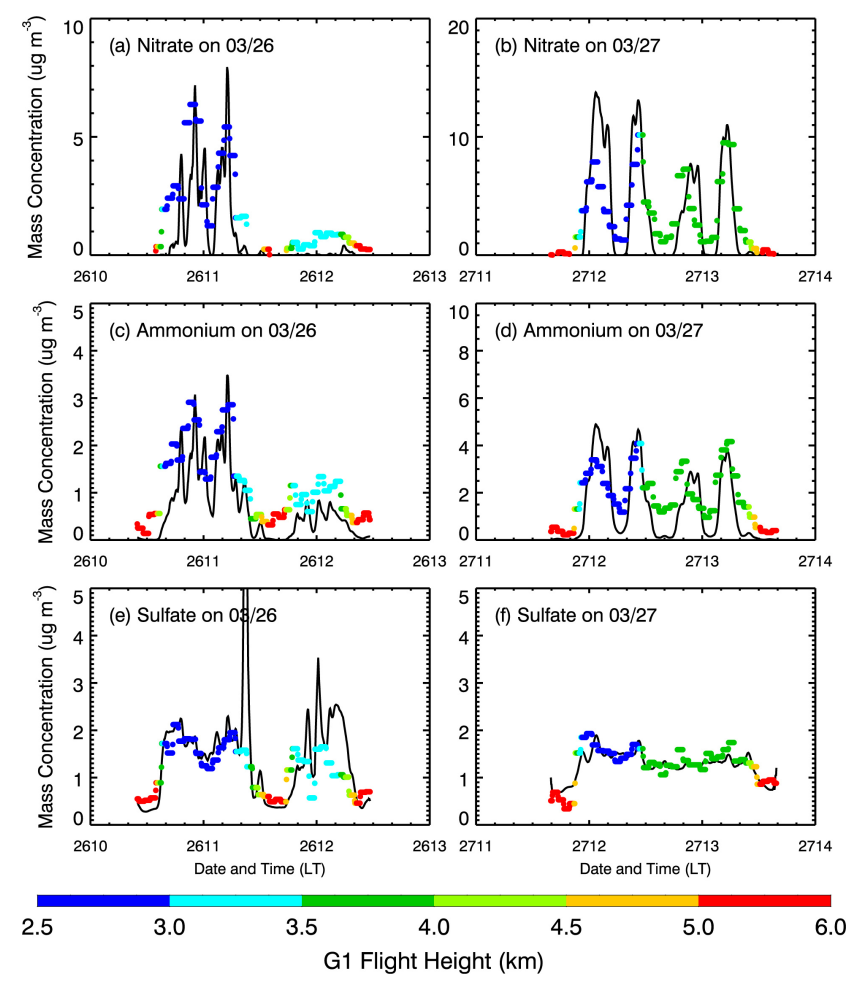

Fig. 3. Comparison of G-1 aircraft measured (dots with different colors) and simulated (black line) nitrate, ammonium, and sulfate aerosols along the flight tracks on 26 and 27 March . See Fig. 2 for the $\mathrm{x}$-axis labels.

al., 2007). The WRF-CHEM is capable of reproducing the increase in the AOT from morning to afternoon, resulting from the accumulation of pollutants and the enhancement
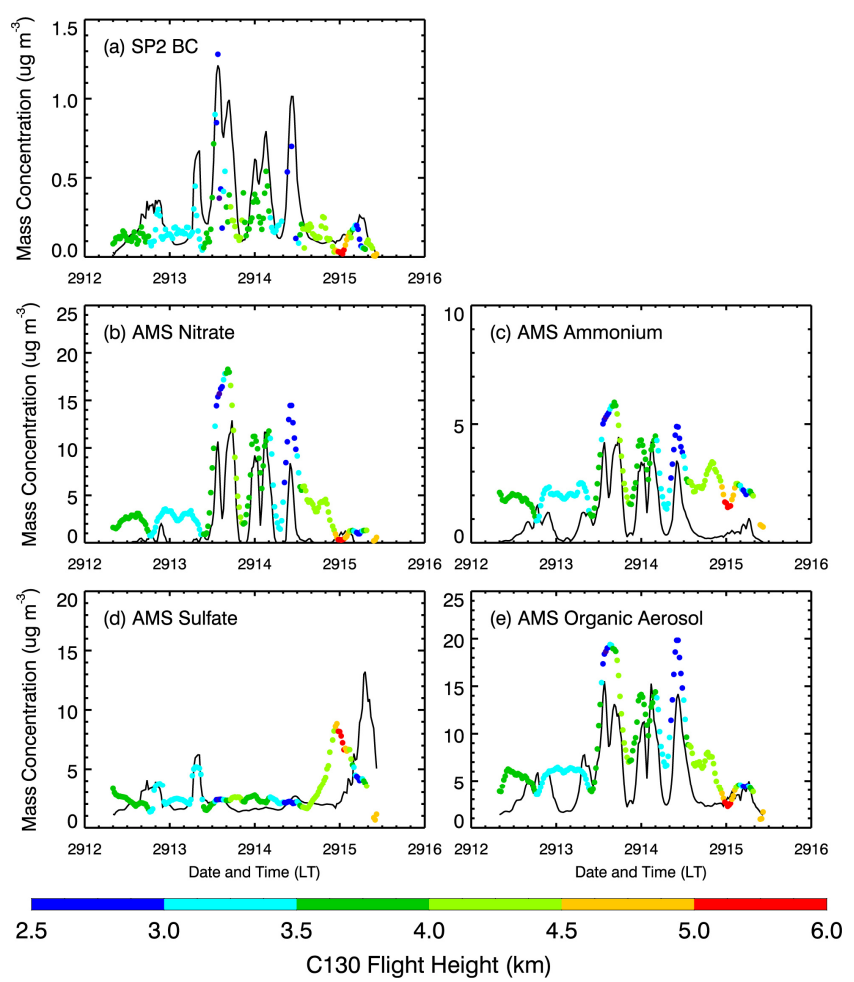

Fig. 4. Comparison of C-130 aircraft measured (dots with different colors) and simulated (black line) BC, nitrate, ammonium, sulfate, and organic aerosols along the flight track on 29 March. See Fig. 2 for the $\mathrm{x}$-axis labels.

of secondary aerosols in the boundary layer (Fig. 5a). The calculated AOT is also comparable to the measured value at T0. The AOT at $550 \mathrm{~nm}$ from MODIS (Moderate Resolution 

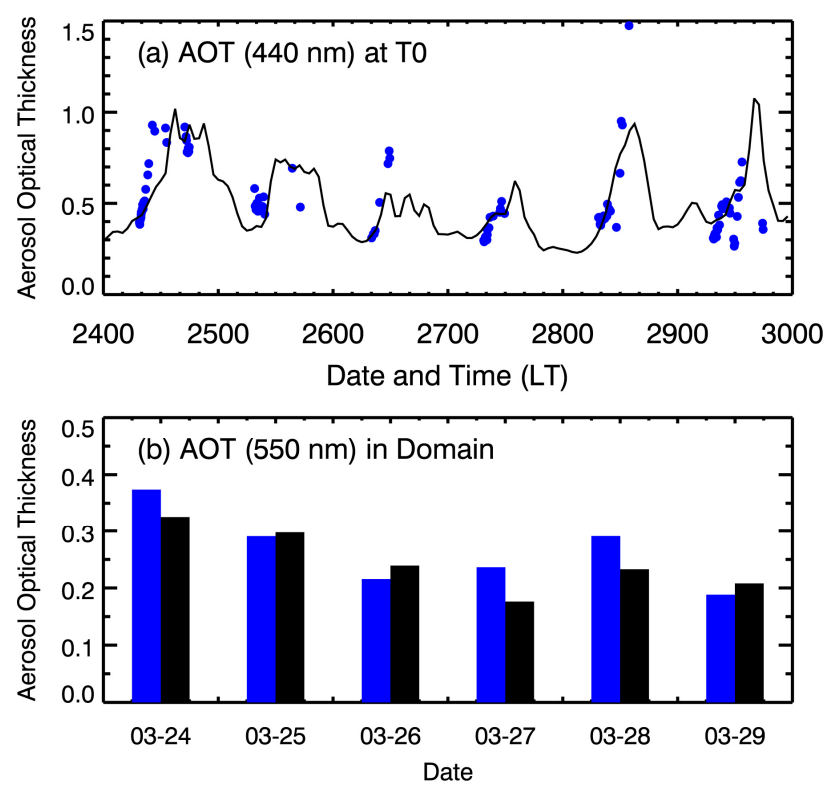

Fig. 5. (a) Diurnal variations of measured (blue dots) and simulated (black line) aerosol optical thickness at T0 and (b) daily and domain averaged MODIS measured (blue) and calculated (black) aerosol optical thickness during the period from 24 to 29 March 2006. See Fig. 2 for the $\mathrm{x}$-axis labels in (a). The $\mathrm{x}$-axis labels (named date) in (b) represent month and day (MM-DD). For example, 03-24 represents 24 March.

Imaging Spectroradiometer) aerosol level-3 product (with a spatial resolution of $1^{\circ} \times 1^{\circ}$ ) is also compared with the model results. Considering the absence of some AOT measurements from satellites due to cloudiness, the comparison is made only on the grid points with the measurements in the domain. Figure $5 \mathrm{~b}$ shows the observed and simulated daily variation of AOT averaged over the model domain. In general, the simulated AOT is in good agreement with the MODIS measurements. Considering the uncertainties from measurements and aerosol simulations, the model reproduce reasonably well the measured AOT values, based on the above mentioned aerosol radiative module.

The aerosol SSA is defined as the ratio of aerosol scattering to total extinction (absorption + scattering):

$\mathrm{SSA}=\frac{\kappa_{S}}{\kappa_{\mathrm{S}}+\kappa_{\mathrm{a}}}$

where $\kappa_{\mathrm{S}}$ is aerosol scattering coefficient and $\kappa_{\mathrm{a}}$ is aerosol absorption coefficient. The SSA is dependent on aerosol chemical composition and morphology, ranging from about 0.2 for freshly emitted diesel soot up to 1.0 for highly scattering aerosols, such as sulfate and nitrate (Ramanathan et al., 2001).

Figure 6 shows the comparison of simulated aerosol SSA with measurements at T0 and from G-1 and C-130 research aircraft. The observed values of SSA $(550 \mathrm{~nm})$ at T0 range from 0.47 to 0.92 with an average of 0.71 during the simu-
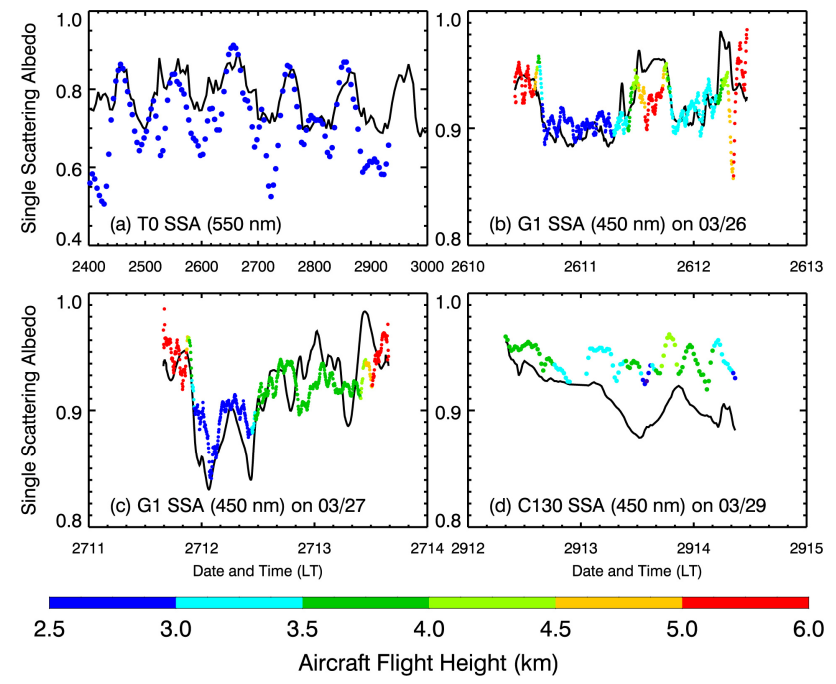

Fig. 6. SSA comparison at T0 and along the aircraft tracks. For (a), the black line represents model simulations and blue dots are measurements at T0. For (b), (c), and (d), dots with different colors are aircraft measurements and the black line represents the model results. See Fig. 2 for the $\mathrm{x}$-axis labels.

lation period. The low values of SSA during the nighttime and rush hours suggest that there are high levels of absorbing aerosols during these periods (Fig. 2). The WRF-CHEM model generally reproduces the diurnal variation of SSA at T0 compared to the measurements, with high levels of SSA during the noontime and low levels during the nighttime and rush hours. However, the model considerably overestimates the observation at T0 during the nighttime and rush hours. For the first episode, the overestimation of nighttime SSA is mainly caused by the sulfate aerosols, which are transported from the Tula industrial complex to the measurement site. Underestimation of absorbing aerosols (BC and POA) is the main reason for the overestimation of SSA during the nighttime and rush hours in the second episode. Nevertheless, the daytime simulations of SSA are generally consistent with the measurements at T0, which is mainly used to study the impact of aerosols on solar radiation.

On 26 March, the simulated variability of SSA $(450 \mathrm{~nm})$ along the flight tracks is generally consistent with the measurement from G-1, except when the plumes are influenced by the events when sulfate aerosols are heavily affected by the Tula industrial complex. The observed values of SSA vary from 0.80 to 0.99 , with an average of 0.92 , indicating that the formation of secondary aerosols enhances the SSA aloft considerably. The simulated SSA is close to 0.92 averaged along the G-1 aircraft track, in spite of the overestimation caused by the sulfate transported from the Tula industrial complex, which can be explained by the occasional underestimation of SSAs by the model. On 27 March, the WRF-CHEM model reasonably follows the observed SSAs before 12:30 LT. However, after 12:30 LT, the variation of 

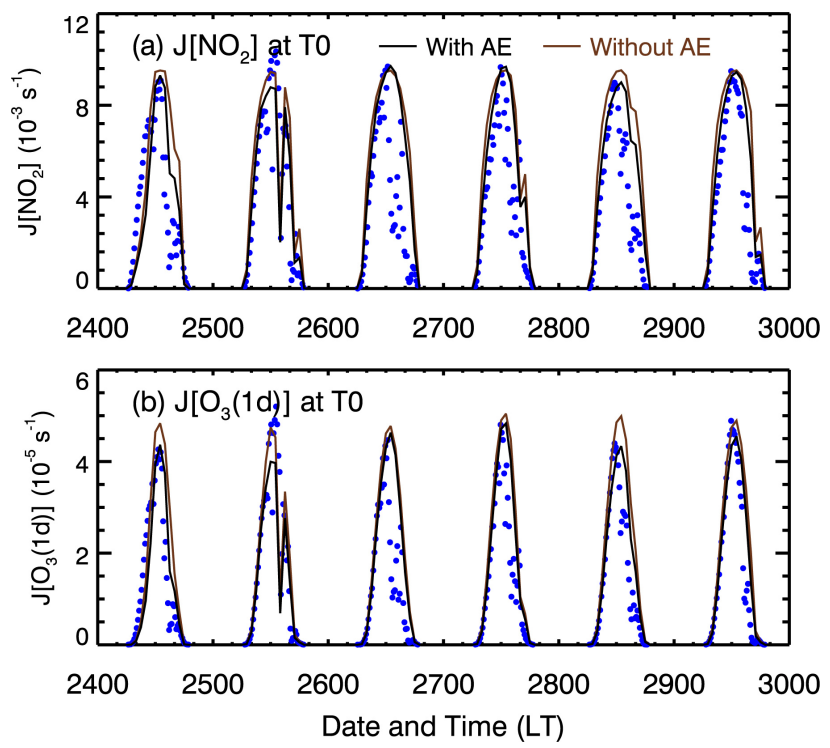

Fig. 7. Diurnal variations of photolysis frequencies of $J\left[\mathrm{O}_{3}\left({ }^{1} \mathrm{D}\right)\right]$ and $J\left[\mathrm{NO}_{2}\right]$ at T0 during the period from 24 to 29 March 2006. Blue dots: measurements; black line: with the aerosol effect on photolysis frequencies; brown line: without the aerosol effect on photolysis frequencies. See Fig. 2 for the x-axis labels.

simulated SSAs is delayed by about 10 min compared to the measurements. On 29 March, the underestimation of scattering aerosols of nitrate, ammonium, and organic carbon results in the lower SSAs compared with the C-130 observation, while the simulated $\mathrm{BC}$, the main absorbing aerosol, is comparable to the measurements.

\subsection{Aerosol impacts on photolysis rates}

The impacts of aerosols on photolysis rates are calculated and analyzed using the radiation model (FTUV) and the above mentioned aerosol radiation module. There are two key photolysis rates affecting tropospheric ozone photochemistry, the $\mathrm{NO}_{2}$ photolysis $\left(J\left[\mathrm{NO}_{2}\right]\right)$ to form the ground state oxygen atom $\mathrm{O}\left({ }^{3} \mathrm{P}\right)$ and the $\mathrm{O}_{3}$ photolysis $\left(J\left[\mathrm{O}_{3}\left({ }^{1} \mathrm{D}\right)\right]\right)$ to form the electronically excited $\mathrm{O}\left({ }^{1} \mathrm{D}\right)$ atom, which are considered in the study:

$$
\begin{aligned}
& \mathrm{O}_{3}+h v \rightarrow \mathrm{O}_{2}+\mathrm{O}\left({ }^{1} \mathrm{D}\right) \quad(290 \mathrm{~nm}<\lambda<329 \mathrm{~nm}) \\
& \mathrm{NO}_{2}+h v \rightarrow \mathrm{NO}+\mathrm{O}\left({ }^{3} \mathrm{P}\right) \quad(290 \mathrm{~nm}<\lambda<420 \mathrm{~nm})
\end{aligned}
$$

Figure 7 shows the diurnal variation of $J\left[\mathrm{O}_{3}\left({ }^{1} \mathrm{D}\right)\right]$ and $J\left[\mathrm{NO}_{2}\right]$ at $\mathrm{T} 0$, where photolysis frequencies for $J\left[\mathrm{O}_{3}\left({ }^{1} \mathrm{D}\right)\right]$ and $J\left[\mathrm{NO}_{2}\right]$ are directly measured using a spectroradiometer as described by Sheehy et al. (2010) and Dusanter et al. (2009), with uncertainties of about $25 \%$ for $J\left[\mathrm{O}_{3}\left({ }^{1} \mathrm{D}\right)\right]$ and $15 \%$ for $J\left[\mathrm{NO}_{2}\right]$. The calculated $J\left[\mathrm{O}_{3}\left({ }^{1} \mathrm{D}\right)\right]$ and $J\left[\mathrm{NO}_{2}\right]$ diurnal variations are consistent with the measurements at T0 under clear sky conditions. However, the WRFCHEM model cannot resolve reasonably well the impact of

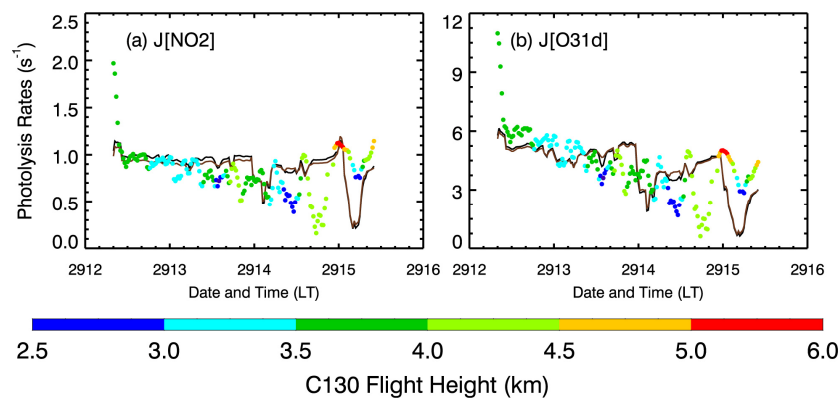

Fig. 8. Comparison of C-130 aircraft measured and calculated photolysis frequencies of $J\left[\mathrm{O}_{3}\left({ }^{1} \mathrm{D}\right)\right]$ and $J\left[\mathrm{NO}_{2}\right]$ along the flight track on 29 March. Dots with different colors: measurements; black line: with the aerosol effect on photolysis frequencies; brown line: without the aerosol effect on photolysis frequencies. See Fig. 2 for the $\mathrm{x}$-axis labels.

clouds on the photolysis frequencies. For example, the measured photolysis frequencies often exhibit large fluctuations in the afternoon due to cumulus clouds, which are only well reproduced on 25 March by the model.

When the effects of aerosols on photolysis frequencies are included in the WRF-CHEM model, the calculated $J\left[\mathrm{O}_{3}\left({ }^{1} \mathrm{D}\right)\right]$ and $J\left[\mathrm{NO}_{2}\right]$ are generally more consistent with the observations at $\mathrm{T} 0$. The model calculation also suggests that the impacts of aerosols on $J\left[\mathrm{O}_{3}\left({ }^{1} \mathrm{D}\right)\right]$ and $J\left[\mathrm{NO}_{2}\right]$ are different. For example, aerosols decrease $J\left[\mathrm{O}_{3}\left({ }^{1} \mathrm{D}\right)\right]$ consistently during the entire episodes at $\mathrm{T} 0$, but the reduction is more pronounced on 24, 25, and 28 March than on the other days. Aerosols also appreciably decrease $J\left[\mathrm{NO}_{2}\right]$ on 24,25 , and $28 \mathrm{March}$, but the reduction is not as substantial as that for $J\left[\mathrm{O}_{3}\left({ }^{1} \mathrm{D}\right)\right]$; during the noontime on 26 and 27 March, aerosols even enhance $J\left[\mathrm{NO}_{2}\right]$ slightly. In the present study, the calculated SSA in the UV band in the boundary layer is around 0.72 to 0.76 , indicating an efficient absorption of UV radiation by aerosols during daytime in Mexico City. Therefore, aerosols generally reduce the photolysis coefficients in the urban area in Mexico City, which is consistent with the previous study (Castro et al., 2001). However, during noontime, the simulated aerosol average effective radius in the boundary layer ranges from 0.26 to $0.40 \mu \mathrm{m}$, which is comparable to the wavelength of the incoming UV radiation. According to the Mie scattering theory, when the size of the particles is similar to the UV wavelength, the incoming radiation is favored to be scattered in the forward directions. As a result, the calculated asymmetry factor in the boundary layer during the noontime is about 0.7 , causing the scattering intensity of aerosols to be peaked at $45^{\circ}$ toward the forward direction. The high diffusely scattered UV radiation possibly exceeds the UV absorption by aerosols, thus enhancing the photolysis coefficients in the boundary layer.

The calculated $J\left[\mathrm{O}_{3}\left({ }^{1} \mathrm{D}\right)\right]$ and $J\left[\mathrm{NO}_{2}\right]$ are also compared with the observation from the C-130 aircraft on 29 March (see Fig. 8). The calculations are generally comparable to the 


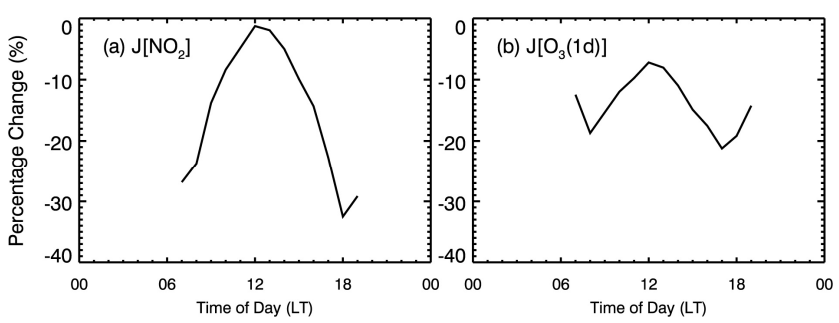

Fig. 9. Daily cycle of the percentage change of $J\left[\mathrm{O}_{3}\left({ }^{1} \mathrm{D}\right)\right]$ and $J\left[\mathrm{NO}_{2}\right]$ averaged over RAMA sites and during the period from 24 to 29 March 2006 when the aerosol effect on the photolysis frequencies is considered.

aircraft measurement, but the impacts of small-scale clouds on the photolysis coefficients cannot be well simulated by the WRF-CHEM model. For example, at the beginning, the C-130 observed high photolysis coefficients at around 3.5 to $4.0 \mathrm{~km}$ compared to those at the same altitude in the other time, even above $5 \mathrm{~km}$, indicating that the aircraft flew over clouds that significantly enhance the photolysis coefficients above them (Liao et al., 1999). Along the aircraft flight track, aerosols increase or decrease $J\left[\mathrm{O}_{3}\left({ }^{1} \mathrm{D}\right)\right]$ and $J\left[\mathrm{NO}_{2}\right]$, depending on the domination of UV scattering or UV absorption by aerosols. During the Photochemical Activity and Ultraviolet Radiation campaign, radiative transfer model calculations and airborne measurements have shown that the absorbing dust aerosols reduce actinic flux (280$420 \mathrm{~nm}$ ) and photolysis rates (Balis et al., 2002; Hofzumahaus et al., 2002).

Figure 9 shows the diurnal variation of the percentage change of $J\left[\mathrm{O}_{3}\left({ }^{1} \mathrm{D}\right)\right]$ and $J\left[\mathrm{NO}_{2}\right]$ averaged over RAMA (Mexico City Ambient Air Monitoring Network) sites. The reduction of $J\left[\mathrm{O}_{3}\left({ }^{1} \mathrm{D}\right)\right]$ and $J\left[\mathrm{NO}_{2}\right]$ due to aerosols is significant in the early morning and late afternoon when the solar zenith angle (SZA) is large, indicating the effect of long aerosol optical path for incoming radiation. With the decrease of SZA around noontime, the impact of aerosols on photolysis frequencies decreases, particularly for the effect of $J\left[\mathrm{NO}_{2}\right]$, with the change approaching zero.

In this study, we evaluate the effects of aerosols on photolysis frequencies with detailed consideration of aerosol size, composition and mixing. The impacts of aerosols on photolysis frequencies are similar to those previously reported by Jacobson (1998). Using a three-dimensional model with a size- and composition-resolved aerosol module, Jacobson (1998) studied the effects of aerosols on vertical photolysis rate coefficients within and over an urban airshed in Los Angeles. He found that in the boundary layer when UV scattering dominates UV absorption by aerosols, aerosols increase photolysis coefficients of UV-absorbing gases and vice versa. Our results are also comparable to that obtained by Liao et al. (1999), in which non-absorbing aerosols, such as sulfate, generally enhance photolysis rates above and in the upper part of the aerosol layer while soot aerosols decrease photolysis rates in the atmosphere; aerosol mixtures could decrease or increase photolysis rates, depending on SSA, SZA and altitude (Liao et al., 1999). It is worthy to note that Castro et al. (2001) found that in Mexico City, the reductions in surface $J\left[\mathrm{NO}_{2}\right]$ by $10-30 \%$ could be attributed to the presence of aerosols. However, in the present study, during noontime, the reduction of $J\left[\mathrm{NO}_{2}\right]$ due to aerosols is less than $10 \%$. Moreover, we find that in some cases, aerosols produce an enhancement of $J\left[\mathrm{NO}_{2}\right]$. One of the possible explanations is that since the 1990s, significant improvements of air quality in the MCMA have been achieved (Molina and Molina, 2002). The study performed by Castro et al. (2001) was based on the observation in 1994, but the present study focuses on the MILAGRO-2006 field campaign. During the time period from 1994 to 2006, substantial reductions in the concentrations of gas phase pollutants and particles have been achieved in Mexico City (Molina et al, 2010). In addition, in the study of Castro et al. (2001), the aerosol size, composition, and mixing are not considered in detail, which also likely contribute to the difference with the present study.

\subsection{Aerosol impacts on photochemistry}

The photolysis frequencies of $J\left[\mathrm{O}_{3}\left({ }^{1} \mathrm{D}\right)\right]$ and $J\left[\mathrm{NO}_{2}\right]$ play a key role in the formation of $\mathrm{O}_{3}$ and $\mathrm{OH}$ in the troposphere. In the polluted atmosphere, the $\mathrm{O}_{3}$ formation mechanism can be expressed as follows:

$$
\begin{aligned}
& \mathrm{NO}_{2}+h v \rightarrow \mathrm{NO}+\mathrm{O}\left({ }^{3} \mathrm{P}\right) \quad(290 \mathrm{~nm}<\lambda<420 \mathrm{~nm}) \\
& \mathrm{O}\left({ }^{3} \mathrm{P}\right)+\mathrm{O}_{2}+M \rightarrow \mathrm{O}_{3}+M \\
& \mathrm{O}_{3}+h v \rightarrow \mathrm{O}_{2}+\mathrm{O}\left({ }^{1} \mathrm{D}\right) \quad(290 \mathrm{~nm}<\lambda<329 \mathrm{~nm}) \\
& \mathrm{O}\left({ }^{1} \mathrm{D}\right)+\mathrm{H}_{2} \mathrm{O} \rightarrow 2 \mathrm{OH} \\
& \mathrm{OH}+\mathrm{VOCs}+\mathrm{O}_{2} \rightarrow \mathrm{RO}_{2}+\text { others } \\
& \mathrm{RO}_{2}+\mathrm{NO} \rightarrow \mathrm{RO}+\mathrm{NO}_{2}
\end{aligned}
$$

Variation of $J\left[\mathrm{O}_{3}\left({ }^{1} \mathrm{D}\right)\right]$ and $J\left[\mathrm{NO}_{2}\right]$ strongly influence the $\mathrm{O}_{3}$ formation and $\mathrm{OH}$ concentrations.

Figure 10 shows the percentage change in surface $\mathrm{O}_{3}$ concentrations at 10:00 and 14:00 LT from 24 to 29 March 2006 when the effects of aerosols on the photolysis frequencies are considered. At 10:00 LT, the impact of aerosols on $\mathrm{O}_{3}$ in the urban area is highest on 24 March (about 5-20\% reduction in $\mathrm{O}_{3}$ concentration) and minimal on 26 March (less than $10 \%$ reduction in $\mathrm{O}_{3}$ level); while on the other days, the $\mathrm{O}_{3}$ level is decreased by about $2-15 \%$. At 14:00 LT, the impact of aerosols on $\mathrm{O}_{3}$ concentrations is less than $10 \%$. In addition, the $\mathrm{O}_{3}$ reduction due to aerosols is mainly located within the pollutant plumes; in contrast, outside of the plumes, aerosols even slightly enhance surface $\mathrm{O}_{3}$ concentrations due to the domination of scattering. Figure 11a and $b$ 

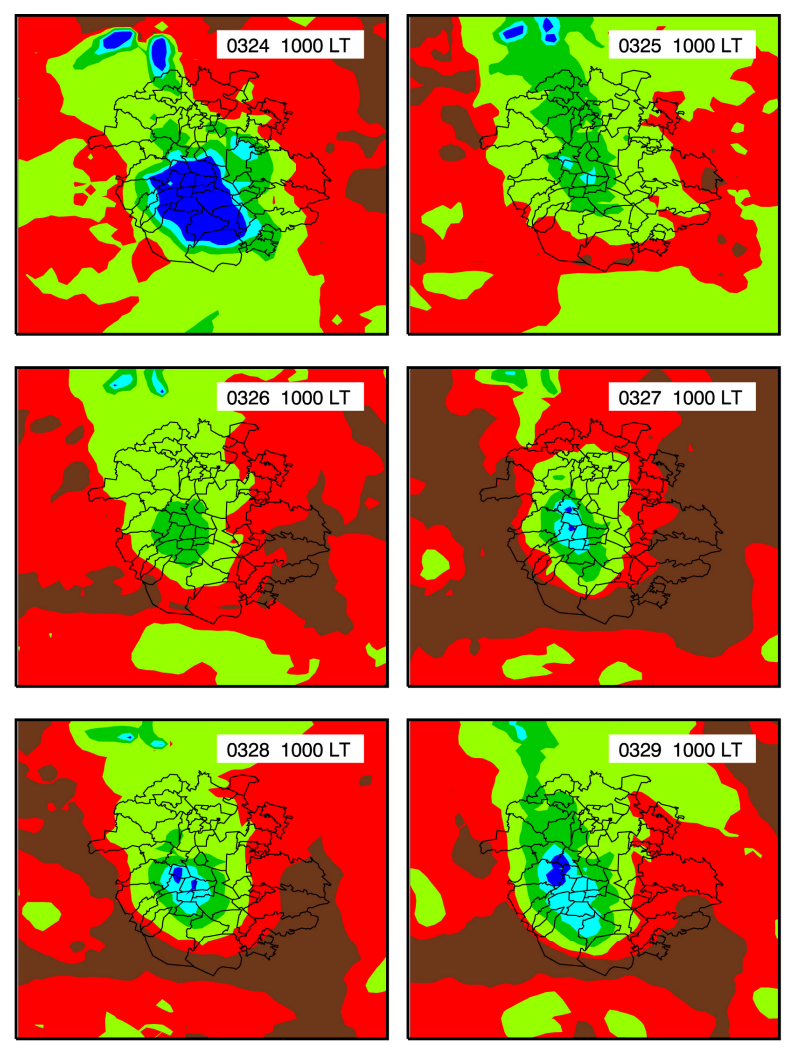

$-20$

(a)

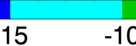

${ }_{3}$ precentage change $(\%)$

Fig. 10. Percentage change in surface $\mathrm{O}_{3}$ concentrations at 10:00 and 14:00 LT from 24 to 29 March 2006 when the aerosol effect on the photolysis frequencies is taken into account.

display the diurnal cycle of the percentage change of $\mathrm{O}_{3}$ and $\mathrm{OH}$ averaged over twenty-one RAMA sites, respectively. On average, in the urban area, the impact of aerosols on $\mathrm{O}_{3}$ formation is most significant in the morning, with the reduction of $\mathrm{O}_{3}$ by $5-20 \%$. In the afternoon, the reduction of $\mathrm{O}_{3}$ due to aerosols is less than $5 \%$. This study shows that the impacts of aerosols on ozone concentrations in Mexico City are comparable to that reported by Jacobson (1998), in which photolysis coefficients changes due to aerosols decrease nearsurface $\mathrm{O}_{3}$ mixing ratio in Los Angeles by 5-8\%. However, the impact of aerosols on $\mathrm{O}_{3}$ in the present study is not as large as those reported by Castro et al. (2001). Based on the calculation of a simple zero-dimensional photochemical model, they have found that surface $\mathrm{O}_{3}$ concentrations in Mexico City could be higher by several tens of ppb if the incident solar UV radiation were not attenuated by aerosols. In this study, even on 25 March when the aerosol impacts on $\mathrm{O}_{3}$ are highest, the average $\mathrm{O}_{3}$ reduction in the urban area is less than $10 \mathrm{ppb}$, which is substantially lower than the value reported by Castro et al. (2001). The percentage change of
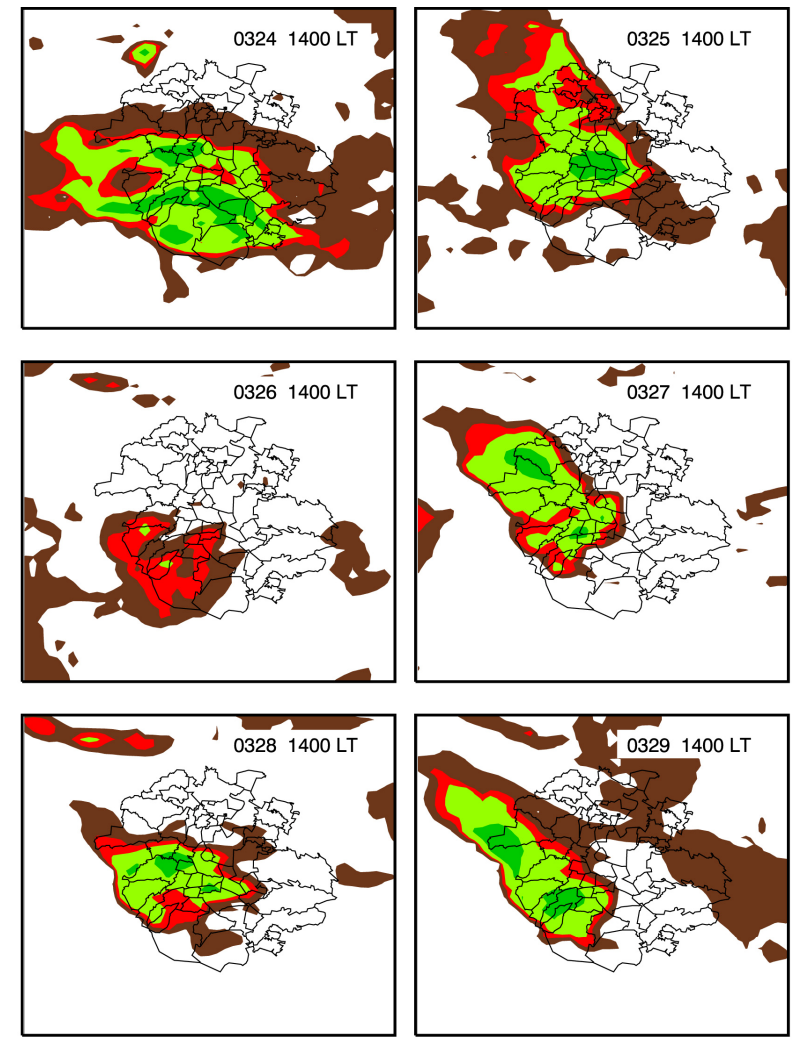

\section{$-20$}

(b)

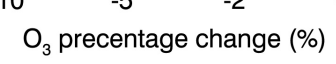

Fig. 10. Continued.

$\mathrm{OH}$ due to aerosols exhibit two nadirs in the early morning and late afternoon, corresponding to the longest aerosol optical path for incoming UV radiation (Fig. 11b). On average, the daytime $\mathrm{OH}$ level in the urban area is decreased by about $9 \%$ by aerosols.

The $\mathrm{OH}$ level in the atmosphere directly determines the oxidation rate of the precursors of secondary aerosols. For the nitrate aerosol, its precursor $\left(\mathrm{HNO}_{3}\right)$ is mainly from the reaction of $\mathrm{NO}_{2}$ with $\mathrm{OH}$. Oxidation products of VOCs and semi-VOCs by $\mathrm{OH}$ are the most important precursors of SOA. Therefore, the decrease of $\mathrm{OH}$ level due to aerosols will influence the formation of secondary aerosol by reducing their precursor concentrations. Figure $11 \mathrm{c}$ and $\mathrm{d}$ show the percentage change of nitrate and SOA averaged over RAMA sites, respectively; their concentrations are reduced in the early morning by more than $10 \%$. However, in the afternoon, the reduction of nitrate aerosols due to aerosols is only about $2 \%$ on average, which is attributed to the increase of $\mathrm{NO}_{2}$ caused by the reduction of $J\left[\mathrm{NO}_{2}\right]$, which partially compensates the decrease of the $\mathrm{OH}$ level for the $\mathrm{HNO}_{3}$ formation. The nitrate and SOA concentrations are decreased by around $5 \%$ and $6 \%$ in the urban area during daytime on average, 

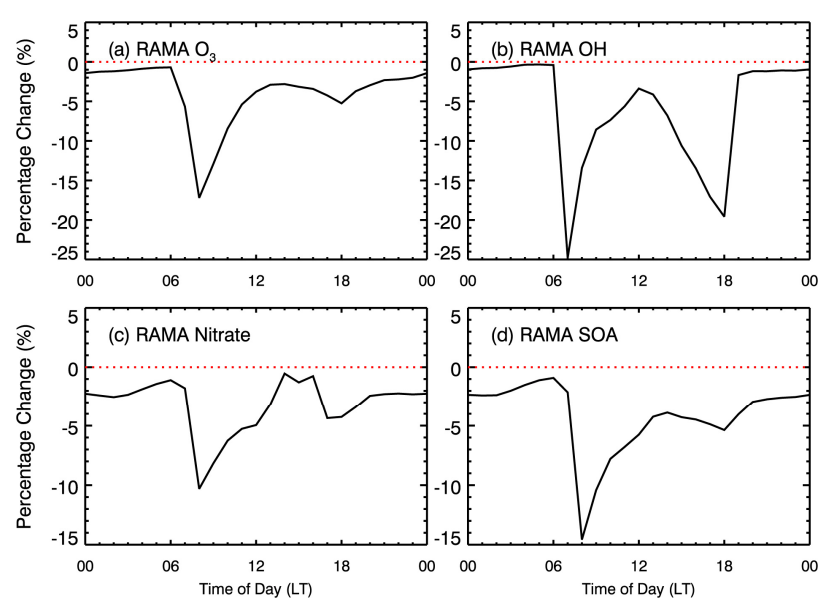

Fig. 11. Same as Fig. 10, but for the surface (a) $\mathrm{O}_{3}$, (b) $\mathrm{OH}$, (c) $\mathrm{Ni}$ trate, and (d) SOA concentrations.

respectively. For sulfate aerosols, because of the inefficient conversion of $\mathrm{H}_{2} \mathrm{SO}_{4}$ from $\mathrm{SO}_{2}$ reaction with $\mathrm{OH}$, the impact of aerosols to its concentrations is negligible, less than $1 \%$ during daytime on average in the urban area.

\subsection{Sensitivity studies}

In the base case simulations, several recent findings of aerosols, such as the rapid aging of $\mathrm{BC}$ and enhanced absorption of UV radiation by POA observed in Mexico City are considered in this study (Moffet and Prather, 2009; Barnard et al., 2008). Furthermore, three sensitivity studies are performed to evaluate the contributions of these findings to the aerosol absorption. In the first sensitivity study, the $\mathrm{BC}$ aging timescale is set to 1.5 day (Cooke and Wilson, 1996); in the second study, the refractive index of POA is set to those of $\mathrm{SOA}$; the third study includes the changes in both first and second cases. For the convenience of the analysis, we define the aerosol absorption factor as:

$\alpha=1-\mathrm{SSA}=\frac{\kappa_{\mathrm{a}}}{\kappa_{\mathrm{S}}+\kappa_{\mathrm{a}}}$

Figure 12a and $\mathrm{b}$ present the diurnal cycle of the aerosol absorption factor averaged over RAMA sites and during the simulation period. The rapid aging of $\mathrm{BC}$ and the enhanced UV radiation absorption by POA significantly influence the aerosol absorption, contributing $21 \%$ at $550 \mathrm{~nm}$ and $38 \%$ at $400 \mathrm{~nm}$ to $\alpha$, respectively. The rapid aging of BC plays a more important role in the aerosol absorption during daytime than at nighttime, but the other way around for the enhanced UV radiation absorption by POA because of the evaporation of POA to form SOA. In addition, during daytime, at $550 \mathrm{~nm}$, the contribution of the rapid aging of $\mathrm{BC}$ to the aerosol absorption is about twice that from the enhanced UV radiation absorption by POA, but at $400 \mathrm{~nm}$, their contributions are almost the same. When the rapid aging of $\mathrm{BC}$ and the enhanced UV radiation absorption by POA are not considered
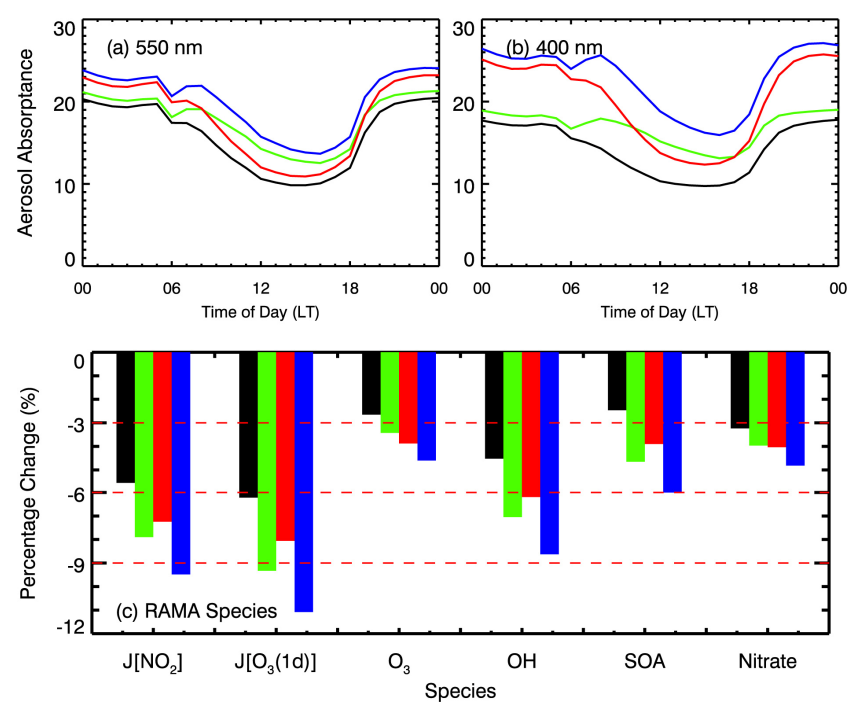

Fig. 12. Daily cycle of the percentage change of aerosol absorbance at (a) $550 \mathrm{~nm}$ and (b) $400 \mathrm{~nm}$ averaged over RAMA sites and during the period from 24 to 29 March 2006 when the aerosol effect on the photolysis frequencies is considered; (c) Percentage change of $J\left[\mathrm{O}_{3}\left({ }^{1} \mathrm{D}\right)\right], J\left[\mathrm{NO}_{2}\right], \mathrm{O}_{3}, \mathrm{OH}, \mathrm{SOA}$, and nitrate due to aerosols averaged over RAMA sites and during the period from 24 to 29 March 2006. Black: without the rapid aging of BC and enhanced UV-radiation absorption by POA; red, without the rapid aging of BC; green: without the enhanced UV-radiation absorption by POA; blue: the base case.

in the third sensitivity study, compared with the results in the base case, the $J\left[\mathrm{O}_{3}\left({ }^{1} \mathrm{D}\right)\right]$ and $J\left[\mathrm{NO}_{2}\right]$ reductions due to aerosols in the urban area are decreased by $41 \%$ and $44 \%$ on average during daytime, respectively (Fig. 12c). Correspondingly, the impacts of aerosols on $\mathrm{O}_{3}$ and $\mathrm{OH}$ concentrations in the urban area are significantly reduced by more than $40 \%$ without consideration of the rapid aging of $\mathrm{BC}$ and the enhanced UV radiation absorption by POA. In addition, the contribution of these two processes to the aerosol absorption and photochemistry is comparable in this study (Fig. 12c).

\section{Conclusions}

We have developed an aerosol radiative module with detailed consideration of aerosol size, composition and mixing, and coupled it into the WRF-CHEM model to evaluate the aerosol impacts on the photochemistry in Mexico City. Sixday simulations from 24 to 29 March during the MCMA2006/MILAGRO have been performed with and without the aerosol impacts on photolysis frequencies and concentrations of atmospheric oxidants and aerosols; the model results have been compared with the available surface, aircraft and satellite observations. 
The WRF-CHEM model performs reasonably well in simulating aerosols in the urban area compared with the measurements at T0, although it has difficulties in simulating sulfate aerosols, which are influenced by multiple sources with substantial emission uncertainties in Mexico City. Compared with the aircraft measurements, the model generally captures the plumes formed over the city and the simulated aerosol concentrations are also comparable to the observations. Reasonable simulations of aerosol temporal variations and spatial distributions provide a necessary bolster for the evaluation of the effects of aerosols on the photochemistry.

The calculated aerosol optical properties are verified using the available measurements from the surface site, aircraft and satellite. The simulated AOT is generally consistent with the measurements from an AERONET site and MODIS. The WRF-CHEM model overestimates the SSA in the urban area compared with measurements at T0 during nighttime, but it reasonably reproduces the variations of the SSA during daytime. Compared with the research aircraft observations, the model is capable of reproducing the temporal and geographical variations of SSA, but there is large discrepancy between simulated and observed values of SSA when the model considerably overestimate or underestimate the secondary inorganic and organic aerosols along the aircraft flight tracks.

The calculated photolysis frequencies of $J\left[\mathrm{O}_{3}(1 \mathrm{D})\right]$ and $J\left[\mathrm{NO}_{2}\right]$ are compared with ground-based and aircraft measurements, showing a good agreement between the calculated and measured values. Inclusion of aerosol effects yields better agreement between the calculated and measured values. The impact of aerosols on photolysis frequencies is significant during the early morning and late afternoon hours, and the reduction of $J\left[\mathrm{O}_{3}\left({ }^{1} \mathrm{D}\right)\right]$ and $J\left[\mathrm{NO}_{2}\right]$ due to aerosols is about $10-30 \%$. Around noontime, with the growth of aerosol particles and the decrease of the SZA, aerosols reduce $J\left[\mathrm{NO}_{2}\right]$ by $1-5 \%$ and $J\left[\mathrm{O}_{3}\left({ }^{1} \mathrm{D}\right)\right]$ by $7-10 \%$ in the urban area on average due to the larger scattering of UV radiation. The decrease in photolysis frequencies leads to a reduction in the surface $\mathrm{O}_{3}$ concentrations in the urban area in Mexico City. On average, the impact of aerosols on $\mathrm{O}_{3}$ formation is most pronounced in the morning with the $\mathrm{O}_{3}$ reduction of 5-20\%; but the $\mathrm{O}_{3}$ reduction is less than $5 \%$ in the afternoon. The daytime $\mathrm{OH}$ level is also decreased by about $9 \%$ due to the presence of aerosols; in addition, the impacts of aerosols on photolysis frequencies appreciably decrease the daytime concentrations of nitrate and SOA by $5-6 \%$ in the urban area on average.

Our sensitivity studies indicate that the rapid aging of $\mathrm{BC}$ and the enhanced UV radiation absorption by POA play an important role in the aerosol absorption in Mexico City, which lead to about $40 \%$ of $\mathrm{O}_{3}$ reduction due to the aerosol impact on photolysis frequencies. This demonstrates the importance of accounting for the contribution of the rapid aging of $\mathrm{BC}$ and the enhanced UV radiation absorption by POA when evaluating the impact of aerosols on the photochemistry in the atmosphere.
There are several implications to the present study. In Mexico City, a large amount of BC and POA are emitted to the atmosphere (Zavala et al., 2009), causing strong absorption of UV radiation during daytime. However, high levels of non-absorbing aerosols, such as SOA, sulfate, nitrate and ammonium, efficiently scatter UV radiation. Aerosols can enhance photolysis frequencies when UV scattering dominates UV absorption by aerosols or vice versa. In most of the megacities and large urban complexes in the United States, the observed BC concentrations are lower (Murphy et al., 2011), so the change in photolysis frequencies due to aerosols is likely to be positive. In contrast, very high POA and $\mathrm{BC}$ emissions in the megacities in China have caused the reduction of photolysis frequencies and ozone concentrations (Bian et al., 2007). In addition, the aerosol radiative module developed in the present study is based on the aerosol modal approach in CMAQ, which is now widely used in air pollution simulations. Considering its efficiency and accuracy demonstrated in the present study, the module provides a powerful tool for evaluating the aerosol impact on the photochemistry in megacities.

It should be noted that when calculating the photolysis rates in the FTUV, the two-stream approximation is used to solve the radiative transfer equation to obtain the actinic flux. The two-stream method divides the multiple scattering contributions into two components, representing by the asymmetry factor $(g)$, and upward and downward fluxes are calculated by solving two coupled differential equations. Generally, in radiative transfer calculations, the more streams that are adopted in the radiation scheme, the more accurate is the calculated radiation field. Therefore, in the two-stream method, errors are caused by using just the asymmetry factor rather than the full scattering function or very low angular resolution. Kay et al. (2001) found that the two-stream approximation had considerable errors at the cloud base and top, whereas the $\delta$-four stream approximation had negligible errors. More accurate methods to calculate actinic flux need to be considered in the future study, but are beyond the scope of the present study.

Acknowledgements. We are indebted to the large number of people involved in the MILAGRO field campaign as well as those involved in long-term air quality monitoring and the emissions inventory in the Mexico City metropolitan area, which made this study possible. This work was supported by the US National Science Foundation's Atmospheric Chemistry Program (ATM-0528227 and ATM-0810931) and the Molina Center for Energy and the Environment. Guohui Li is a Molina Fellow at MIT. Acknowledgment is also made to the National Center for Atmospheric Research, which is sponsored by the National Science Foundation, for the computing time used in this research.

Edited by: M. Gauss 


\section{References}

Barnard, J. C., Volkamer, R., and Kassianov, E. I.: Estimation of the mass absorption cross section of the organic carbon component of aerosols in the Mexico City Metropolitan Area, Atmos. Chem. Phys., 8, 6665-6679, doi:10.5194/acp-8-6665-2008, 2008.

Bian, H. and Zender, C. S.: Mineral dust and global tropospheric chemistry: Relative roles of photolysis and heterogeneous uptake, J. Geophys. Res., 108(D21), 4672, doi:10.1029/2002JD003143, 2003.

Bian, H., Prather, M. J., and Takemura, T.: Tropospheric aerosol impacts on trace gas budgets through photolysis, J. Geophys. Res., 108(D8), 4242, doi:10.1029/2002JD002743, 2003.

Bian, H., Han, S., Tie, X., Sun, M., and Liu, A.: Evidence of impact of aerosols on surface ozone concentration in Tianjin, China, Atmos. Environ., 41, 4672-4681, 2007.

Balis, D. S., Zerefos, C. S., Kourtidis, K., Bais, A. F., Hofzumahaus, A., Kraus, A., Schmitt, R., Blumthaler, M., and Gobbi, G. P.: Measurements and modeling of photolysis rates during the Photochemical Activity and Ultraviolet Radiation (PAUR) II campaign, J. Geophys. Res., 107(D18), 8138, doi:10.1029/2000JD000136, 2002.

Binkowski, F. S. and Roselle, S. J.: Models-3 Community Multiscale Air Quality (CMAQ) model aerosol component: 1. Model description, J. Geophys. Res., 108(D6), 4183, doi:10.1029/2001JD001409, 2003.

Castro, T., Madronich, S., Rivale, S., Muhlia, A., and Mar B.: The influence of aerosols on photochemical smog in Mexico City, Atmos. Environ., 35, 1765-1772, 2001.

Chen, F. and Dudhia, J.: Coupling an advanced land-surface/hydrology model with the Penn State/NCARMM5modelingsystem. Part I: Model description and implementation, Mon. Weather Rev., 129, 569-585, 2001.

Cooke, W. and Wilson, J.: A global black carbon aerosol model, J. Geophys. Res., 101(D14), 19395-19409, 1996.

de Almeida Castanho, A. D., Prinn, R., Martins, V., Herold, M., Ichoku, C., and Molina, L. T.: Analysis of Visible/SWIR surface reflectance ratios for aerosol retrievals from satellite in Mexico City urban area, Atmos. Chem. Phys., 7, 5467-5477, 2007, http://www.atmos-chem-phys.net/7/5467/2007/.

de Foy, B., Fast, J. D., Paech, S. J., Phillips, D., Walters, J. T., Coulter, R. L., Martin, T. J., Pekour, M. S., Shaw, W. J., Kastendeuch, P. P., Marley, N. A., Retama, A., and Molina, L. T.: Basinscale wind transport during the MILAGRO field campaign and comparison to climatology using cluster analysis, Atmos. Chem. Phys., 8, 1209-1224, doi:10.5194/acp-8-1209-2008, 2008.

de Foy, B., Krotkov, N. A., Bei, N., Herndon, S. C., Huey, L. G., Martínez, A.-P., Ruiz-Suárez, L. G., Wood, E. C., Zavala, M., and Molina, L. T.: Hit from both sides: tracking industrial and volcanic plumes in Mexico City with surface measurements and $\mathrm{OMI} \mathrm{SO}_{2}$ retrievals during the MILAGRO field campaign, Atmos. Chem. Phys., 9, 9599-9617, doi:10.5194/acp-9-9599-2009, 2009.

d'Almeida, Koepke, G. A., P., and Shettle, E. P.: Atmospheric aerosols: global climatology and radiative Characteristics, 261 pp., A. Deepak, Hampton, Va., 1991.

Dickerson, R. R., Kondragunta, S., Stenchikov, G., Civerolo, K. L., Doddridge, B. G., and Holben, B. N.: The impact of aerosols on solar ultraviolet-radiation and photochemical smog, Science,
215, 827-830, 1997.

Dudhia, J.: Numerical study of convection observed during the winter monsoon experiment using a mesoscale two-dimensional model, J. Atmos. Sci., 46, 3077-3107, 1989.

Dusanter, S., Vimal, D., Stevens, P. S., Volkamer, R., Molina, L. T., Baker, A., Meinardi, S., Blake, D., Sheehy, P., Merten, A., Zhang, R., Zheng, J., Fortner, E. C., Junkermann, W., Dubey, M., Rahn, T., Eichinger, B., Lewandowski, P., Prueger, J., and Holder, H.: Measurements of $\mathrm{OH}$ and $\mathrm{HO}_{2}$ concentrations during the MCMA-2006 field campaign - Part 2: Model comparison and radical budget, Atmos. Chem. Phys., 9, 6655-6675, doi:10.5194/acp-9-6655-2009, 2009.

Hofzumahaus, A., Kraus, A. Kylling, A., and Zerefos, C. S.: Solar actinic radiation $(280-420 \mathrm{~nm})$ in the cloud-free troposphere between ground and $12 \mathrm{~km}$ altitude: Measurements and model results, J. Geophys. Res., 107(D18), 8139, doi:10.1029/2001JD900142, 2002.

Horowitz, L. W., Waters, S., Mauzerall, D. L., Emmons, L. K., Rasch, P. J., Tie, X., Lamarque, J.-F. Schultz, M. G., Tyndall, G. S., Orlando, J. J., and Brasseur, G. P.: A global simulation of tropospheric ozone and related tracers: Description and evaluation of MOZART, version 2, J. Geophys. Res., 108(D24), 4784, doi:10.1029/2002JD002853, 2003.

Jacobson, M. Z.: Studying the effects of aerosols on vertical photolysis rate coefficient and temperature profiles over an urban airshed, J. Geophys. Res., 103, 10593-10604, 1998.

Jonson, J. E., Kylling, A., Berntsen, T. K., Isaksen, I. S. A., Zerefos, C. S., and Kourtidis, K.: Chemical effects of UV fluctuations inferred from total ozone and tropospheric aerosol variations, J. Geophys. Res., 105(D11), 14, 561-14, 574, 2000.

Kay, M. J., Box, M. A., Trautmann, T., and Landgraf, J.: Actinic flux and net flux calculations in radiative transfer - A comparative study of computational efficiency, J. Atmos. Sci., 58, 37523761, 2001.

Kirchstetter, T. W., Novakov, T., and Hobbs, P. V.: Evidence that the spectral dependence of light absorption by aerosols is affected by organic carbon, J. Geophys. Res., 109, D21208, doi:10.1029/2004JD004999, 2004.

Klein, S. A. and Jakob, C.: Validation and sensitivities of frontal clouds simulated by the ECMWF model, Mon. Weather Rev., 127, 2514-2531, 1999.

Koo, B. Y., Ansari, A. S., and Pandis, S. N.: Integrated approaches to modeling the organic and inorganic atmospheric aerosol components, Atmos. Environ., 37, 4757-4768, 2003.

Li, G., Zhang, R., Fan, J., and Tie, X.: Impacts of black carbon aerosol on photolysis and ozone, J. Geophys. Res., 110, D23206, doi:10.1029/2005JD005898, 2005.

Li, G., Lei, W., Zavala, M., Volkamer, R., Dusanter, S., Stevens, P., and Molina, L. T.: Impacts of HONO sources on the photochemistry in Mexico City during the MCMA-2006/MILAGO campaign, Atmos. Chem. Phys., 10, 6551-6567, doi:10.5194/acp10-6551-2010, 2010.

Li, G., Zavala, M., Lei, W., Tsimpidi, A. P., Karydis, V. A., Pandis, S. N., Canagaratna, M. R., and Molina, L. T.: Simulations of organic aerosol concentrations in Mexico City using the WRFCHEM model during the MCMA-2006/MILAGRO campaign, Atmos. Chem. Phys., 11, 3789-3809, doi:10.5194/acp-11-37892011, 2011.

Liao, H., Yung, Y. L., and Seinfeld, J. H.: Effects of aerosols on 
tropospheric photolysis rates in clear and cloudy atmospheres, J. Geophys. Res., 104(D19), 23697-23707, 1999.

Lin, Y.-L., Farley, R. D., and Orville, H. D.: Bulk parameterization of the snow field in a cloud model, J. Appl. Meteorol., 22, 10651092, 1983.

Marley, N. A., Gaffney, J. S., Castro, T., Salcido, A., and Frederick, J.: Measurements of aerosol absorption and scattering in the Mexico City Metropolitan Area during the MILAGRO field campaign: a comparison of results from the T0 and T1 sites, Atmos. Chem. Phys., 9, 189-206, doi:10.5194/acp-9-189-2009, 2009.

Matthijsen, J., Suhre, K., Rosset, R., Eisele, F., Mauldin, R., and Tanner, D.: Photodissociation and UV radiative transfer in a cloudy atmosphere: Modeling and measurements, J. Geophys. Res., 103, 16665-16676, 1998.

Martin, R. V., Jacob, D. J., Yantosca, R. M., Chin, M., and Ginoux, P.: Global and regional decreases in tropospheric oxidants from photochemical effects of aerosols, J. Geophys. Res., 108(D3), 4097, doi:10.1029/2002JD002622, 2003.

Mlawer, E. J., Taubman, S. J., Brown, P. D., Iacono, M. J., and Clough, S. A.: Radiative transfer for inhomogeneous atmosphere: RRTM, a validated correlated-k model for the long-wave J. Geophys. Res., 102(D14), 16663-16682, 1997.

Moffet, R. C. and Prather, K.: In-situ measurements of the mixing state and optical properties of soot with implications for radiative forcing estimates, P. Natl. Acad. Sci., 106(29), 11872-11877, 2009.

Molina, L. T. and Molina, M. J.: Air Quality in the Mexico Megacity: An Integrated Assessment, Kluwer Academic Publishers: Dordrecht, The Netherlands, 384 pp, 2002.

Molina, L. T., Kolb, C. E., de Foy, B., Lamb, B. K., Brune, W. H., Jimenez, J. L., Ramos-Villegas, R., Sarmiento, J., ParamoFigueroa, V. H., Cardenas, B., Gutierrez-Avedoy, V., and Molina, M. J.: Air quality in North America's most populous city overview of the MCMA-2003 campaign, Atmos. Chem. Phys., 7, 2447-2473, doi:10.5194/acp-7-2447-2007, 2007.

Molina, L. T., Madronich, S., Gaffney, J. S., Apel, E., de Foy, B., Fast, J., Ferrare, R., Herndon, S., Jimenez, J. L., Lamb, B., Osornio-Vargas, A. R., Russell, P., Schauer, J. J., Stevens, P. S., Volkamer, R., and Zavala, M.: An overview of the MILAGRO 2006 campaign: Mexico City emissions and their transport and transformation, Atmos. Chem. Phys., 10, 8697-8760, doi:10.5194/acp-10-8697-2010, 2010.

Murphy, D. M., Chow, J. C., Leibensperger, E. M., Malm, W. C., Pitchford, M., Schichtel, B. A., Watson, J. G., and White, W. H.: Decreases in elemental carbon and fine particle mass in the United States, Atmos. Chem. Phys., 11, 4679-4686, doi:10.5194/acp-11-4679-2011, 2011.

Noh, Y., Cheon, W. G., and Raasch, S.: The improvement of the Kprofile model for the PBL using LES. Preprints, Int. Workshop of Next Generation NWP Models, Seoul, South Korea, Laboratory for Atmospheric Modeling Research, 65-66, 2001.

Odum, J. R., Hoffman, T., Bowman, F., Collins, D., Flagan, R. C., and Seinfeld, J. H.: Gas/particle partitioning and secondary organic aerosol yields, Environ. Sci. Technol., 30, 2580-2585, 1996.

Penner, J. E., Andreae, M. O., Annegarn, H., Barrie, L., Feichter, J., Hegg, D., Jayaraman, A., Leaitch, R., Murphy, D., Nganga, J., and Pitari, G.: Aerosols, their direct and indirect effects, in: Climate Change 2001: The Scientific Basis, Contributions of Work- ing Group I to the Third Assessment Report of the Intergovernmental Panel on Climate Change, edited by: Houghton, J. T., Ding, Y., Griggs, D. J., Noguer, M., van der Linden, P. J., Dai, X., Maskell K., and Johnson, C. A., Cambridge University Press, Cambridge, UK, and New York, NY, USA, 289-348, 2001.

Ramanathan, V., Crutzen, P. J., Kiehl, J. T., and Rosenfeld, D.: Aerosols, climate, and the hydrological cycle, Science, 7, 21192124, 2001.

Sheehy, P. M., Volkamer, R., Molina, L. T., and Molina, M. J.: Oxidative capacity of the Mexico City atmosphere - Part 2: A $\mathrm{RO}_{\mathrm{x}}$ radical cycling perspective, Atmos. Chem. Phys., 10, 69937008, doi:10.5194/acp-10-6993-2010, 2010.

Shrivastava, M. K., Lane, T. E., Donahue, N. M., Pandis, S. N., and Robinson, A. L.: Effects of gas-particle partitioning and aging of primary emissions on urban and regional organic aerosol concentrations, J. Geophys. Res., 113, D18301, doi:10.1029/2007JD009735, 2008.

Song, J., Lei, W., Bei, N., Zavala, M., de Foy, B., Volkamer, R., Cardenas, B., Zheng, J., Zhang, R., and Molina, L. T.: Ozone response to emission changes: a modeling study during the MCMA-2006/MILAGRO campaign, Atmos. Chem. Phys., 10, 3827-3846, doi:10.5194/acp-10-3827-2010, 2010.

Stockwell, W. R. and Goliff, W. S.: Measurement of actinic flux and the calculation of photolysis rate parameters for the Central California Ozone Study, Atmos. Environ., 38, 5169-5177, 2004.

Tie, X., Madronich, S., Walters, S., Zhang, R., Rasch, P., and Collins, W.: Effect of clouds on photolysis and oxidants in the troposphere, J. Geophys. Res., 108(D20), 4642, doi:10.1029/2003JD003659, 2003.

Tie, X., Madronich, S., Walters, S., Edwards, D. P., Ginoux, P., Mahowald, N., Zhang, R., Lou, C., and Brasseur, G.: Assessment of the global impact of aerosols on tropospheric oxidants, J. Geophys. Res., 110, D03204, doi:10.1029/2004JD005359, 2005.

Tsimpidi, A. P., Karydis, V. A., Zavala, M., Lei, W., Molina, L., Ulbrich, I. M., Jimenez, J. L., and Pandis, S. N.: Evaluation of the volatility basis-set approach for the simulation of organic aerosol formation in the Mexico City metropolitan area, Atmos. Chem. Phys., 10, 525-546, doi:10.5194/acp-10-525-2010, 2010.

Wesely, M. L.: Parameterization of surface resistance to gaseous dry deposition in regional-scale numerical models, Atmos. Environ., 23, 1293-1304, 1989.

Zanis, P., Kourtidis, K., Rappenglueck, B., Zerefos, C., Melas, D., Balis, D., Schmitt, R., Rapsomanikis, S., and Fabian, P.: A case study on the possible link between surface ozone photochemistry and total ozone column during the PAUR II experiment at Crete: Comparison of observations with box model calculations, J. Geophys. Res., 107(D18), 8136, doi:10.1029/2000JD000137, 2002.

Zavala, M., Herndon, S. C., Wood, E. C., Jayne, J. T., Nelson, D. D., Trimborn, A. M., Dunlea, E., Knighton, W. B., Mendoza, A., Allen, D. T., Kolb, C. E., Molina, M. J., and Molina, L. T.: Comparison of emissions from on-road sources using a mobile laboratory under various driving and operational sampling modes, Atmos. Chem. Phys., 9, 1-14, doi:10.5194/acp-9-1-2009, 2009.

Zhang, R., Li, G., Fan, J., Wu, D. L., and Molina, M. J.: Intensification of Pacific storm track linked to Asian pollution, P. Natl. Acad. Sci. USA, 104, 5295-5299, doi:10.1073/pnas.0700618104, 2007. 